\author{
БЕЗЕНА Іван Михайлович - \\ кандидат філософських наук, \\ завідувач кафедри соціально-гуманітарної освіти \\ КЗВО «Дніпровська академія неперервної освіти» \\ ORCID:https://orcid.org/0000-0002-7169-2038 \\ e-mail: ivanbezen@ukr.net
}

\title{
ВЧИТЕЛЬ ТА ШКОЛЯР: ПЕДАГОГІКА ІНДИВІДУАЛЬНОСТІ У ОСВІТНЬОМУ ПОСТУПІ ЧЕРЕЗ ВЗАЕМНУ ДОВІРУ
}

\begin{abstract}
Постановка та обгрунтування актуальності проблеми. Сучасна людина постає в суспільстві, через процеси вибудовування власного життя, які проходять у контекстах оточуючого середовища та iii учасників: родини, однолітки, колектив, заклад освіти, громада тощо. В даному контексті для суспільства важливо, щоб особистість була готова до самостійного творення власного життя в гармонії i3 суспільством та іншими особистостями. Не заперечно, що для сучасної особистості, особливу вагу мають зовнішні фактори, які впливають своїм ставленням і оцінками суб'єкта життєтворчості та випробують його на міцність емоційно-духовного запалу.
\end{abstract}

Наша сучасна школа, іiі освітній зміст, та суб'єкт реалізації змістової освітньої програми вчитель, все потребує нового переосмислення за змістом освіти, iii структури i індивідуалізація освітньої траєкторії за потребами особистості. Свого часу було сформовано національну концепцію шкільної освіти, яка концентрувалась на стратегічних ідеях - дитиноцентризму та гуманізму, але процеси їх реалізації в більшості випадків конкретної практики, це були лише гасла, без конкретного, кропіткого і послідовного наповнення.

Тому, сьогодні, державна концепція «Нова українська школа» надала поштовх загальній середній освіті: переходу на новий зміст освіти, оптимізацію навчальних дисциплін, їх тематичного наповнення; формування освітнього порталу та методичного забезпечення на допомогу вчителю, що сприятиме застосуванню нових інтерактивних педагогічних технологій, направлених на розвиток школяра.

Сучасне інноваційно-цифрове суспільство вже нагально потребує особистості, яка самостійна, спроможна i саморозвиваюча, громадянськоактивна, гармонійна, збалансована із своїм внутрішнім «Я», суспільством і природою, духовно i психологічно спроможної до автономної діяльності та відповідальної поведінки у соціальному просторі суспільства. Фактично основний пласт виконання окреслених освітніх пріоритетів, суспільство покладає на вчителя та школу.

Мета статті - співставити філософськопедагогічні ідеї Івана Зязюна із сучасними концептами шкільної освіти, які окреслюють місію вчителя у формуванні школяра через взаємну довіру. Окреслені питання знаходять свого наукового дослідження, як в національному, так і в зарубіжному науковому середовищі.

Виклад основного матеріалу дослідження. Основною діяльнісною особою у сучасній розбудові шкільництва за концепцією «Нова українська школа» $\epsilon$ вчитель. Його професійна діяльність, визначає освітній результат шкільної освіти - зміст, рівень і якість життєвих компетентностей здобувача освіти, які орієнтовані на самостійне і активне життя. Адже від діяльності педагога, його професійності, ціннісного досвіду та його життєвої мудрості, спроможності вирішувати професійні задачі будь-якої складності - від практичних до методологічних, які впливають на успішність результату. Індикаторами процесів особистісного пізнання і результатів діяльності педагога, можуть виступати: його кваліфікація, життєві компетентності, педагогічна творчість та індивідуальна майстерність.

Лещенко М. досліджуючи філософську спадщину Івана Зязюна відмічає значимість його поглядів на питання педагогічної майстерності вчителя, як його внутрішньо-духовну здатність «<..> забезпечувати цілісний розвиток учнів» [1, c. 263]. На нашу думку, дійсно, сучасний вчитель перебуває у досить особливому життєвому стані: 3 однієї сторони, є суспільні вимоги у державних стандартів та програмах, а 3 іншої - життєдайна інформація/знання та іiі практичне застосування особистістю в реальних життєвих моделюючих історіях, не обмежуючи рамок свободи їх діяльності.

Вчитель, як стратег, який має відповідну професійну основу, мудра людина, яка має прогнозувати та враховувати виклики сучасного життя, які постійно змінюють соціальне середовище, суспільство та особистість. Сучасна особистість, інколи плануючи власний життєвий процес, враховує або не враховує життєві чинники, які призводять до того, що може отримати не ті результати, на які він розраховував. А надалі, його осмислення i внутрішні фактори особистості можуть привести до двох висновків: перший оцінити самого себе, другий - перекладають відповідальність за наслідки діяльності на зовнішні фактори/явища. Саме, освітнє середовище має сформувати навички критичного мислення у відношенні власної діяльності та зовнішніх чинників.

Дослідниця Гнізділова О. відзначає, що Іван 
Зязюн $є$ «<... фундатором нового напряму педагогічної науки і засновником наукової школи 3 проблем педагогічної майстерності, < ..> він довів, що мрії про професію здійснюються, успіх приходить до того, хто наполегливо працює й постійно самовдосконалюється <...>» [2, с. 13]. Майстерність та професійність вчителя особливо актуалізується у сучасному шкільному середовищі орієнтованому на структурні зміни у шкільництві. Від професійної діяльності вчителя у значній мірі залежить, чи буде створено передумови для формування у особистості суспільно значимих якостей, серед яких особливе місце займає культура свободи життєвої діяльності у процесах самореалізації в суспільстві. Свобода особистості один 3 визначальних критеріїв вільного, демократичного і цивілізованого суспільства, змістовно-складовий індикатор індивідуального світоглядного бачення та розумного підходу до розвитку соціуму через окремі особистості.

На нашу думку, однією з визначальних рис сучасної цифрової цивілізації $є$ посилення актуальності особистісного та відповідальноіндивідуального виміру буття, що у свою чергу значно актуалізує традиційну філософську концепцію свободи і культури свободи, через нові і синергетично зорієнтовані процеси та сенси суспільного співіснування індивідів. У сучасному цивілізованому суспільстві вільна, освічена i культурно-зорієнтована особистість виступає основою демократичного громадянського суспільства.

Свобода особистості - один 3 визначальних критеріїв вільного цивілізованого суспільства, змістовний визначник гуманістичного підходу до соціуму через сучасне, динамічне, гнучке i перспективне його бачення. На думку Кена Робінсона «<... школа прагне допомогти учням досягнути успіху, надаючи їм можливості налагодити тісні особистісні стосунки, що впливають на всі аспекти життя <...>»[3, с. 201].

Лише, постійно рефлексуюча людина спроможна пізнати власну значимість свободи i зрозуміти всі можливі життєві ризики у процесах рухів до свободи, яка $\epsilon$, i необхідністю, i особистісною потребою. Вказаний рух $\epsilon$ визначальним у індивідуальній діяльності, яка формується на основі особистісної внутрішньої волі та чіткості мети, кінцевим результатом таких дій можуть стати, як уявно окреслені, так непередбачувані результати. Кожна особистість має власні уявлення про свободу: у одного - це особистісна спроможність вільно діяти без будьякого обмеження, «а там, що буде», для іншого суб'єкта - це можливість вільної діяльності у окресленому «від - до», тобто суспільно відповідальному чітко окресленому векторі та із урахуванням інтересів інших індивідів, для окремих індивідів - $є$ постійний страх за можливі наслідки своїх дій. В той же час, ми можемо говорити, що у поданих контекстах від стану свободи до загального хаосу, один крок. Тому, щоб не піти по шляху хаосу, нігілізму та в певній мірі індивідуального емоційно-психологічного насилля над іншими індивідами, суспільство встановлює прийнятні правила та визначає межі правил «від - до».

Ми розуміємо, що сучасна людина - це надскладна система, яка відкрита, динамічна, гнучка, здатна до самоорганізації, для досягнення власно окресленої мети. Але в певних умовах вона потребує стимулів та власної волі для досягнення окреслених мрій та мети. В даних концептах, для людини є особливими питання: освіта, самоосвіта та саморозвиток протягом всього життя. Безумовно, сьогодні актуалізується давнокитайська мудрість викладена у наступному: «наскільки волю зміниш, настільки й лінощі меншими стануть» [4, с. 53].

У результаті, саме від відкритості і активності людини в освітній та життєвій діяльності, залежить індивідуальний результат. При такому стані речей, особистість, освічена людина, як динамічна система, завжди буде відкрита до змін, трансформацій та коректив у діяльності. К. Ясперс змістовно відмічає: «<..>людина не може бути завершеною, для того щоб бути, вона повинна змінюватися у часі, підкоряючись все новій долі $<\ldots>$. $[5$, с. 114].

Виходячи із вище окреслених концептів, сучасна освіта має поставати у конструктивному роздвоєнні: перед запитом особистості щодо індивідуальної освітньої траєкторії розвитку школяра; структурованому розмаїтті освітнього середовища, яке задовольнятиме окреслені запити. Відзначене відповідно, $з$ однієї сторони, суспільством та державою визначено вектори змісту освіти у стандартах, програмах, підручниках, методиках, які входять до загальнообов'язкового державного компоненту, а 3 іншої сторони, індивідуальні запити особистості на свободу i вольовий розвиток, предметні уподобання, їх кількість, форми і цілі подальшої освітньої траєкторії. Актуальність давньогрецької мудрості, $\epsilon$ досить очевидною і у сучасні часи: «не для школи, для життя навчання».

У будь якої особистості у процесі освітньої діяльності формується внутрішня потреба сформувати принципи i компетенції, які будуть індивідуалізувати іiі, для реалізації життєвих цілей людини. Актуалізується значення особистості, яка знає чого вона хоче, розуміє яким шляхом йти до окресленого та якими принципами керуватися у даному процесі. Тобто, вказане можна викласти із застосуванням актуальної думки дослідниці проблеми Култаєвої М., що особистість вже сама сформує бачення для себе, «<..> які дари брати від свободи, як взагалі навчитися обирати <...> [6]

Зокрема, ми відзначаємо, що ще не повністю досліджена проблема сучасної школи: родина та дитина, її опіка (інколи надмірна) в концепті освіти, адже часом постає помилкове визначення іiї освітніх цілей та визначення власних потенціалів. В окресленому контексті постає питання: на скільки суспільство спроможне визначити межі родинного регулювання і втручання у процеси розвитку та 
перетворення дитини в школі. Адже, інколи у школяра формується стан «життєвої залежності» від думки та діяльності батьків. У даних контекстах актуальними є проблема академічної доброчесності від батьків, які інколи не надають можливості дітям самостійно долати трудності (резільєнтність особистості), формування у дитини викривлених стереотипів норм поведінки 3 елементами хизування, ігнорування думки інших, прагнення відстояти «особливі умови» для дитини, відволікання дитини від «пізнання себе» тощо. У даному контексті актуальна думка Сенеки, що «<... природні бажання мають межу, породжені викривленою думкою - не знають, на чому зупинитись, <...> адже все викривлене не має меж, $<$...> йдучи по дорозі прийдеш до цілі, але блукання безкінечні <...> [7, с. 42].

Спробуємо, уявити які основні риси притаманні сучасній дитині нового цифрового періоду розвитку людства, чи можемо встановити, що діти XXI століття один в один, як ми, але багато років назад, мабуть все таки ні: вони швидше сприймають інформацію, але менше піi запам'ятовують; можуть із захопленням здійснювати пошук потрібної інформації в мережі Інтернет; не люблять великого числа інформації, швидко втомлюються від іiі змісту, тому потребують iï постійного дозування та зміни форми подачі; не визнають авторитетів, відмічаючи свою самобутність і індивідуальність, шукають свій шлях в житті та повної свободи на цьому тяжкому шляху. Відповідно, в окресленому колі питань визначається ключова проблема: вчитель і школярі - освітне середовище на основі довіри між ними.

А поряд 3 окресленим, постає питання, як готова система сучасної шкільної освіти і масова школа: $є$ заклади освіти, які постійно тримають високий освітній тонус середовища у змісті і якості освіти; є заклади, які вбачають стару основу освітнього середовища, це повну покору особистості, «широкі коридори змісту» навчальної інформації у більшості випадків не потрібної для життя. На жаль, у другої моделі закладів, відзначається відсутність амплітуди навчальної мотивації у дитини, ніхто не робить спроби спитати у нового покоління, яким шляхом навчання вони хочуть йти тощо. Авторитаризм в освітній системі продовжується, але під іншими ідеями, імітацією процесу та старими підходами.

Який вчитель має бути у такого покоління дітей? На наше глибоке переконання, до сьогодні, актуальні напутні слова Сенеки для тих хто вчить інших: по-перше, «<..> краще прийти і побачити на місці <..>», по-друге, «<..> довгий шлях настанов, короткий і вагомий шлях прикладів <...> [7, с.26]. То ми, маємо чесно і професійно відповісти, що хочемо від місії вчителя та школи, що спроможні зробити, а також, що хочемо змінити і які результати отримати на виході 3 освітнього середовища школи.

Можливо тому, ми все частіше звертаємося до окремих зразків зарубіжного досвіду щодо модернізації шкільництва до вимог сучасного суспільства. Але прикро, що не визначено сучасний стан шкільництва в державі, що потрібно змінити в його змісті, аби досягнути ефективного позитивного результату - самореалізації особистості в освітньому просторі та становлення життєвих компетентностей. М. Култаєва слушно відмічає, що «<..> спроби інтенсифікувати процес розвитку дитини у добу прискорення суспільних трансформацій і загальноцивілізаційних зламів пов'язані із численними ризиками <...>» [8]. Адже, сьогодні, дуже гостро постають питання про мотиваційні складові самореалізації особистості у освітньому шкільному процесі, виміру рівня свободи індивіда в навчанні (можливості вибору змісту навчання, форми навчання, навчальних предметів тощо) та подолання відчуження дитини, як в навчанні, так в соціальній комунікації. Гуманізація, дитиноцентризм та людиновимірність є основними цінностями розвитку сучасної шкільної освіти. Наше суспільство, сьогодні, вже відчуває, що відчуження дитини від навчання, було спричинено: відривом отриманого дитиною досвіду у школі від сучасного рівня життя; розривом у ступені важливості життєвого досвіду і компетентностей; станом, у якому особистість вчиться в школі, не вбачаючи майбутніх шляхів практичного застосування шкільних знань.

Успішна самореалізація школяра, у контекстах структурних змін, що відбуваються в освіті, тісно пов'язана $з$ його уявленнями про своє місце в світі, своє покликання і призначення, а рівень свободи освітньої діяльності визначає формує особистісні стимули для розвитку людини. Духовні кризи, які переживає навіть зріла особистість, у часи таких світоглядних пошуків, у школяра характеризується високим рівнем напруження внутрішніх духовнодушевних сил. В той же час, світоглядний оптимізм, сприяє зняттю такого напруження навіть у випадку невдалих спроб самореалізації школяра, орієнтуючи його на самопізнання, вироблення механізмів самоконтролю і самодисципліни, культури свободи діяльності, а в той час, як зневіра через світоглядне сприйняття змін у суспільстві, яка посилює настрої безнадійності, апатії, ліні, втрати віри у життедайність власних сил.

Нами встановлено, що забезпечення культурної самоідентифікації особистості $\epsilon$ головним завданням ціннісно-культурного змісту шкільництва. В процесі національно-культурної ідентифікації у шкільному освітньому просторі дитина ознайомлюється та робить спроби співставляти культури полінаціональної держави і буття народу, із своїм особистим. Змістом педагогічного процесу має стати формування здатності до культурного самовизначення, національна самовизначеність має складатися в процесі свідомого соціального та культурного самовизначення людини. Нова школа має виділити основні культурні компоненти у освітньому процесі, а саме: науково-раціональні, міфологічні та ірраціоналістичні цінності національної культури, 
культури свободи. В даних аспектах Григорій Сковорода осмислюе особистісну проблему самопізнання людини, підносить істинно людське, духовне начало в людині. У самопізнанні, на думку філософа, є сенс людського життя: «<..> дивись на тих людей, чиї слова, діла, <..> коротше кажучи, все життя скероване всередину <...> [9, с. 235].

Пошуки нових та інтерактивних педагогічних технологій навчання дитини, пов'язані з проблемою сутнісного розуміння сучасного покоління дітей, їх форми розуміння та дослідження світу, бачення свого місця у всіх процесах світу, суспільства та розвитку цілісної системи цивілізації. Вже набуло певного окреслення в освітніх системах методи гейміфікації, коли педагоги використовують ігрові технології для неігрових, а у нашій ситуації в навчальних цілях. Не заперечним є значимість самого процесу гри, а він подвоює результати освіти, коли школяр проходить етапи від простого до складного, для життя i практичного застосування, навики виживання у складних життєвих ситуаціях та пошуку шляхів його гуманістичного розв'язання. Впровадження методів машинного навчання для персоналізації навчання особистості, коли школяр самостійно проводить до практичного відпрацювання завдання, а вчитель діагностує i коригує вказану навчальну роботу, пропонує здобувачу освіти нові рівні складності досліджуваної освітньої роботи. Адже знання завжди були і будуть, ознакою сили та мобільності особистості, у будь-яких життєвих обставинах та ситуаціях.

Реформа шкільної освіти окреслила пріоритет освітньої системи через розвиток школяра для майбутнього періоду життя, його компетентностей. Досить слушною, у даному контексті є думка Кена Робінсона «<..> допомогти людям усвідомити глибину їхніх здібностей, <..> спонукати організації повірити у силу інновацій і створити умови, в яких ті процвітатимуть <..>, ми не зможемо успішно маневрувати у складному середовищі майбутнього, якщо без кінця вдивляємось у дзеркало заднього огляду <...> [3]. В окресленому контексті, ми вже відмічали, що занадто завищено стандарти освіти, що особистість має осягнути та мати відповідні компетентності, а можливо певні блоки знання в деякій мірі i непотрібні для їх майбутнього життя [10]. I тим очевидно робимо недобру послугу дитині для іiі розвитку та реалізації в житті. Такими рутинними діями, ми обмежуємо їх прагнення, волю і свободу до інтелектуального та креативного розвитку особистості у сучасному сенсі життя, штовхаємо до інертності та безнадійності.

Педагогічна майстерність, на думку Зязюна I.А., це вияв педагогом власного «Я» та самореалізація у професійній діяльності, що у свою стає прикладом і стимулом для школяра/школярки у процесі саморозвитку. Вона знаходить свій вияв у педагогічній техніці освітньої діяльності вчителя, його мовленні, мисленні, мистецькій діяльності, організації педагогічної взаємодії 3 колегами та батьками. На наше переконання, в контекстах Нової української школи актуалізується думка Зязюна І.А., що «<..> особлива риса педагогічної майстерності - усвідомлення механізмів успішності своєї праці, себе як специфічного «інструмента» роботи 3 людиною» [11]. Дійсно, центром сучасної освітньої системи, яка розпочала реформуватись був і буде вчитель, який $є$ індикатором освітнього руху дитини, консультантом, порадником та мотивом для успішності школяра в школі.

Освіту, Іван Зязюн розглядає, і як педагогічне явище, i одну із найважливіших підсистем суспільства. Освіта є живий процес, у якому місія вчителя створити найкращі умови для зростання школяра, у знаннях, уміннях, навичках, компетентісно-практичному застосуванні отриманих навчальних знань шляхом дослідження й самовираження працюючи в малих групах та індивідуально. Продовжуючи його думку, Кен Робінсон говорить, що «<...> найкращі вчителі - не просто викладачі свого предмету, <..> вони наставники й провідники, які виховують у своїх учнях упевненість, допомагають їм знайти свій шлях i спонукають повірити в себе <..>> [12, c. 115].

На нашу думку, досить актуальним є проблема самоактуалізації педагога, який в процесі освітньої діяльності будучи на високому рівні професійної діяльності та проводить всебічну роботу по самоактуалізації школяра/школярки. Ми відзначаємо, що проводячи зовнішні смислові дослідження щодо діяльності педагога, можна говорити про його «внутрішнє/зовнішнє буття», а саме: повне за змістом, живе за формами i безкорисне за результатами переживання життя 3 повним зосередженням та заглибленням в нього, постійний вибір, здатність взяти на себе відповідальність, уміння прислухатися до себе, виявлення своїх захисті та подолання їх [10].

В сучасному змісті освіти намітились окремі трансформації направлені на формування громадянських компетентностей. Так, з 2017 р. у 10 класі впроваджено у навчальний план предмет: Громадянська освіта, як інтегрований курс розрахований на 70 годин. У програмі курсу передбачено відпрацювання практичних компетенцій, які $\epsilon$ основою сучасного демократичного суспільства: особистість і ідентичність; права і свободи людини; людина у соціокультурному середовищі; демократичне суспільство та його цінності; взаємодія громадян і держави у досягненні суспільного добробуту; світ інформації та мас-медіа; Україна, Свропа, світ. Основна орієнтованість курсу $є$ формування практичних компетентностей громадянина. Зміст громадянської освіти передбачає інтеграцію соціально-гуманітарних знань та орієнтацію на розв'язання практичних проблем інтегративних громадянознавчих знань.

Програма курсу передусім передбачає ознайомлення молодого покоління із «світовими демократичними здобутками та особливостями 
становлення демократії в Україні». Відповідно, що стосується практичної площини, то тут передбачено сформувати мотивацію та основні вміння, потрібні для «відповідальної участі у громадсько-політичних процесах, критично-конструктивне ставлення молоді до життя суспільства», а також набуття школярами досвіду «громадянських дій, демократичної поведінки та конструктивної взаємодії». Крім того, громадянська освіта має сприяти становленню «активної позиції громадян щодо реалізації ідеалів і цінностей демократії в Україні» $[13 ; 14]$.

Окреслюючи окремі підсумки сучасних змістових трансформацій потрібно відзначити, що європейський досвід діяльності у шкільній освіті підтверджує необхідність викладання громадянської освіти, починаючи 3 початкової школи та продовжуючи вивчення на всіх ступенях шкільництва і розширяючи іiі зміст відповідно до вікових особливостей дитини. Друге, є відповідно, нагальна потреба у формуванні навчальнометодичної бази призначеної для вчителя, яка міститиме візуальну, практичну, розвивальну, моделюючу, міркувально-імпровізаційну, аналітичну, порівняльну, проблемно-орієнтовану освітню інформацію [15].

Адже, співпраця вчителя та школярів, зорієнтована на освітній простір через взаємну довіру і ефективному поступ у розвитку особистості молодого покоління. Сучасний вчитель має бути тьютором, фасилітатором, коучем, модератором, а в ході освітнього процесу послідовно навчає активним навичкам співпраці в команді, коли можуть доповнювати один одного, стимулювати до саморозвитку та самовдосконалення. Дістервег А. визначає наступні основи професійності сучасного вчителя, «свідомо йти в ногу 3 сучасністю, пройматися і надихатися силами, що пробудилися в ній» [16].

Висновки та перспективи подальших розвідок напряму. Освітній процес $є$ мережею людських взаємин направлених на формування освітніх та життєвих компетентностей, адже його учасники є відкритими для дискурсу на основі довіри та взаємодії. Окреслені аспекти досліджував та відзначав їх особливу вагу видатний педагог i науковець Іван Зязюн, і це має неоціненне значення для сучасного компетентісного розвитку людини i впровадження реформи освітньої системи. Визначальними філософсько-педагогічними положеннями вченого є ідеї сутності Людини і іiі виховання, педагогічної майстерності вчителя, взаємодовіри в контексті «вчитель-учень/учениця», ключове значення сприятливого і комфортного для освіти дитини процесу.

Таким чином, вчитель є суб'єктом освітньої діяльності, ключовим фактором розвитку для самореалізації особистості в освітньому та життєвому середовищі. Від його ставлення до світу, бачення власного місця в ньому, здатності відтворювати взаємообумовлені зміни у світі та освітній сфері, рівня довіри та сприятливого освітнього середовища залежить результат освічена та самодостатня особистість нового часу. Зміст освіти та іiі якість постають ключовими питаннями діяльності вчителя та наслідком спільної освітньої діяльності з школярами.

У ході розвідок окреслилась наступна проблема, на яку ми визначаємо власні перспективи дослідження - «успіх особистості у самоосвіті» як результат процесів діяльності особистості та його культури свободи, відповідальної свободи.

\section{СПИСОК ДЖЕРЕЛ}

1. Лещенко М. П. Наукова школа академіка Івана Зязюна. / М. П. Лещенко // Становлення i розвиток науково-педагогічних шкіл: проблеми, досвід, перспективи: збірник наукових праць / за ред. В. Кременя, Т. Левовицького - Житомир: Видавництво ЖДУ імені Івана Франка - 2012. - С. 259-269.

2. Гнізділова О. Життєвий шлях та наукова діяльність академіка Іван Андрійовича Зязюна / О. Гнізділова // Витоки педагогічної майстерності - 2015. - Вип. 16. - С.13-19.

3. Робінсон Кен, Ароніка Лу. Школа майбутнього. Революція у вашій школі, що назавжди змінить освіту: пер. $з$ англ. Г. Лелів - Львів: Літопис - 2016. - 258 с.

4. Мудрість народна. Китайські прислів'я та приказки / Упорядкування та передмова В.М'ясникова: Переклад 3 китайської І. Чирка - Київ: Вид. «Дніпро» 1984. $-120 \mathrm{c}$

5. Ясперс К. Духовная ситуация времени. Смысл и назначение истории / К. Ясперс - М. - 1991. - С. 411.

6. Култаєва М. Д. Філософсько-антропологічне обгрунтування культури свободи та його освітні імплікації (теоретичний досвід сучасної німецької філософської думки) / М. Д. Култаєва // Філософія освіти 2009 - №1-2 (8) - URL: http://enpuir.npu.edu.ua/bitstream/123456789/2577/1/Kultaye va.pdf (дата звернення 10.10.2019)

7. Сенека, Марк Аврелий Наедине с собой. Симферополь: «Реноме» - 1998. - 384 с

8. Култаєва М. Д. Суспільне покликання філософії освіти у сучасних соціокультурних контекстах / М. Д. Култаєва // Вісник Харківського національного педагогічного університету імені Г. С. Сковороди. Філософія - 2014. - Вип. 42. - С. 186-194. URL:http://nbuv.gov.ua/UJRN/VKhnpu_filos_2014_42_20. (дата звернення 09.10.2019)

9. Сковорода Г. Твори: У 2-х. томах / Г. Сковорода - Київ. - 1984. - Т.2. - 480 с.

10. Безена I. M. Соціокультурні аспекти самореалізації особистості школяра в контексті структурних змін в освіті / I.М. Безена // Філософія і політологія в контексті сучасної культури. Науковий журнал - 2016. - Вип. 2(11). 228c.

11. Зязюн I. А. Філософія педагогічної якості в системі неперервної освіти. Інноваційні підходи до виховання студентської молоді у вищих навчальних закладах: матеріали Міжнародної науково-практичної конференції / І.А. Зязюн / за редакцією: Дубасенюк О. А., Ковальчук В. А. - Житомир: ЖДУ ім. І. Франка - 2014. C. 8-20. - URL: http://eprints.zu.edu.ua/853/1/05ziasno.pdf (дата звернення 10.10.2019)

12. Робінсон К. Освіта проти таланту. Сила творчості / К. Робінсон: пер. 3 англ. Г. Лелів. - Львів: «Літопис» - 2017. - С.256.

13. Громадянська освіта. Навчальна програма для закладів загальної середньої освіти. Затверджено наказом 
Міністерства освіти і науки України від 20.04.2018 р., № 408. - URL: https://mon.gov.ua/ua/osvita/zagalna-serednyaosvita/navchalni-programi/navchalni-programi-dlya-10-11klasiv(дата звернення 10.10.2019)

14. Садовий M. I. До питання формування компетентностей 3 безпеки життєдіяльності учнів на уроках технологій / М. І. Садовий // Наукові записки ЦДПУ ім. В.Винниченка. Серія: Педагогічні науки. Кропивницький - 2018. - Вип. 173. - С. 88-91.

15. Трифонова О. М. Інформаційно-цифрова компетентність: зарубіжний i вітчизняний досвід / О. М. Трифонова // Наукові записки ЦДПУ ім. В.Винниченка. Серія: Педагогічні науки Кропивницький - 2018. - Вип. 173. - С. 221-225.

16. Дістервег А. Вчитель в школі / А. Дістервег URL: $\quad$ https://naurok.com.ua/vistup-novi-roli-vchitelya-vparadigmi-suchasno-osviti-31224.html(дата звернення 10.10.2019)

\section{REFERENCES}

1. Leshchenko, M. P. (2012) Naukova shkola akademika Ivana Ziaziuna [Scientific school of academician Ivana Zjazjuna]. Zhytomyr.

2. Hnizdilova, O. (2015) Zhyttievyi shliakh ta naukova diialnist akademika Ivan Andriiovycha Zjazjuna [A course of life and scientific activity of academician are Ivan of Andreevich Zjazjuna].

3. Robinson, Ken, Aronika Lu (2016) Shkola maibutnoho. Revoliutsiia u vashii shkoli, shcho nazavzhdy zminyt osvitu [School of the future ] Lviv.

4. Mudrist narodna (1984). Kytaiski pryslivia ta prykazky [Wisdom is folk]. Kyiv.

5. Iaspers, K. (1991) Dukhovnaia sytuatsyia vremeny [Spiritual situation of time]. Moscow.

6. Kultaieva, M. D. (2009) Filosofsko-antropolohichne obgruntuvannia kultury svobody ta yoho osvitni implikatsii (teoretychnyi dosvid suchasnoi nimetskoi filosofskoi dumky) [Philosophical-anthropological ground of culture of freedom and him educational implications]. URL: http://enpuir.npu.edu.ua/bitstream/123456789/2577/1/Kultaye va.pdf(accessed on: 10/10/2019)

7. Seneka, Mark Avrelyi (1998) Naedyne s soboi [In private with itself]. Symferopol

8. Kultaieva, M. D. (2014) Cuspilne poklykannia filosofii osvity u suchasnykh sotsiokulturnykh kontekstakh [of calling of philosophy of education in modern sociocultural contexts].

URL: http://nbuv.gov.ua/UJRN/VKhnpu_filos_2014_42_20.(access ed on: 10/09/2019)

9. Skovoroda, H. (1984) Tvory: U 2-kh.t. [writings]. Kyiv.

10. Bezena, I. M. (2016) Sotsiokulturni aspekty samorealizatsii osobystosti shkoliara $v$ konteksti strukturnykh zmin v osviti [Socio-cultural aspects of self-realization of the student's personality in the context of structural changes in education].
11. Ziaziun, I. A. (2014) Filosofiia pedahohichnoi yakosti $v$ systemi neperervnoi osvity [Philosophy of pedagogical quality is in the system of continuous education].URL: http://eprints.zu.edu.ua/853/1/05ziasno.pdf (accessed on: 10/10/2019)

12. Robinson, K. (2017) Osvita proty talantu. Syla tvorchosti [Education is against talent]. Lviv.

13. Hromadianska osvita (2018). Navchalna prohrama dlia zakladiv zahalnoi serednoi osvity [Civil education]. URL: https://mon.gov.ua/ua/osvita/zagalna-serednyaosvita/navchalni-programi/navchalni-programi-dlya-10-11klasiv (accessed on: 10/10/2019)

14. Sadoviy, M. I.(2018), Do pitannya formuvannya kompetentnostey z bezpeki zhittEdIyalnostI uchnIv na urokah tehnologIy [On the issue of forming competences for students' safety at the lessons of technology]. Kropivnitskiy.

15. Tryfonova, O. M. (2018), Informatsiyno-tsifrova kompetentnist: zarubizhniy $i$ vitchiznyaniy dosvid [Information and digital competence: foreign and domestic experience]. Kropivnitskiy.

16. Disterveh, A. (2000) Vchytel v shkoli [A teacher is at school]. URL: https://naurok.com.ua/vistup-novi-rolivchitelya-v-paradigmi-suchasno-osviti-31224.html (accessed on: $10 / 10 / 2019$ )

\section{ВІДОМОСТІ ПРО АВТОРА}

БЕЗЕНА Іван Михайлович - кандидат філософських наук, завідувач кафедри соціальногуманітарної освіти, Комунальний заклад вищої освіти «Дніпровська академія неперервної освіти» Дніпропетровської обласної ради».

Наукові інтереси: філософія освіти, педагогіка школи, публічне управляння та адміністрування, демократизація освіти, децентралізація.

\section{INFORMATION ABOUT THE AUTHOR}

BEZENA Ivan Mykhajlovich - candidate of philosophical sciences, manager of department of socialhumanitarian education, Communal establishment of higher education the «Dnepr academy of continuous formation» of the Dnepropetrovsk regional soviet».

Circle of research interests: philosophy of education, pedagogics of school, public management and administration, democratization of education, decentralization.

Стаття надійшла до редакиії 25.10.2019 p. 